\title{
8. The securitization of asylum and human rights in Canada and the European Union
}

\section{Idil Atak and François Crépeau}

\section{INTRODUCTION}

Over the past decades, as the number of forcibly displaced persons has reached unprecedented levels around the world, migration and asylum have become critical and debated issues in many countries. Concerns related to security, territorial sovereignty and border control fundamentally changed the playing field of immigration regulation. Beginning in the early 1980s, a number of immigration policy measures, notably visa regimes and carrier sanctions, were either initiated or retooled in order to prevent the irregular arrival of migrants or asylum seekers. National legislations on asylum and immigration have been frequently amended to become stricter. Numerous states have criminalized illegal entry, as well as all help to irregular migration. Excessive penalties have been imposed for migrant smuggling. States have re-emphasized the role of the border as the traditional symbol of national sovereignty. Physical barriers have been erected, border controls strengthened with increasing reliance on technology and military equipment. ${ }^{1}$ Migration controls were also pushed beyond national territory and international cooperation has been increased.

This chapter deals with the securitization of asylum. Securitization is defined as a process of social construction that pushes an area of regular politics, such as asylum, into an area of security. ${ }^{2}$ The issue is therefore

1 François Crépeau, Delphine Nakache and Idil Atak, 'International Migration: Security Concerns and Human Rights Standards' (2007) 44 Transcultural Psychiatry 311, 324.

2 Ole Waever, Barry Buzan, Morten Kelstrup and Pierre Lemaître, Migration and the New Security Agenda in Europe (Pinter, 1993) 65; Barry Buzan, Ole 
described as an existential threat to fundamental values of society and the state, a construction which helps in convincing a relevant section of society that exceptional measures are needed in response to this existential threat. In the name of urgency and survival, these measures often reach above and beyond the law and the ordinary political process. ${ }^{3}$

A comparative approach is adopted to draw attention to the dilemma faced by destination countries, which feel the pressure of migration at their borders and have tried to prevent asylum seekers with an array of deterrent and repressive measures. It is argued that whereas globalization considerably increased the movement of information, goods, capitals, services, as well as of individuals across borders, asylum seekers have been represented as embodying a threat to national security and to public order. The securitization of asylum resulted in the introduction of more restrictive legislative and administrative policies clearly at variance with states' domestic and international obligations of human rights and with the spirit and often the letter of the Convention relating to the Status of Refugees ('1951 Refugee Convention'). ${ }^{4}$

The European Union (EU) and the Canadian situations are the main focus of the chapter, which also draws on similar experience in other Global North countries. ${ }^{5}$ Europe and North America are major destinations for asylum seekers. In 2011, there were 876,100 individual applications for asylum or refugee status submitted to the United Nations High Commissioner for Refugees (UNHCR) or to governments in 171 countries or territories. 301,000 asylum applicants were registered in the 27 EU countries. Canada has received 25,000 applications. ${ }^{6}$ Since the 1980s, securitization has been a major feature of asylum policies in the EU and in Canada. The free movement of persons across the EU's

Waever and Jaap de Wilde, Security: A New Framework for Analysis (Lynne Rienner Publishers, 1998) 33; Giuseppe Campesi, The Arab Spring and the Crisis of the European Border Regime: Manufacturing Emergency in the Lampedusa Crisis, EUI Working Paper RSCAS 2011/59 (2011) 11-12.

3 Philippe Bourbeau, The Securitization of Migration: A Study of Movement and Order (Routledge, 2011) 131.

4 Convention relating to the Status of Refugees, 189 UNTS 150, entered into force 22 April 1954; François Crépeau and Delphine Nakache, 'Controlling Irregular Migration in Canada: Reconciling Security Concerns with Human Rights Protection' (2006) 12 IRPP Choices 12.

5 Eurostat, Asylum Decisions in the EU27 (19 June 2012), available at http://europa.eu/rapid/pressReleasesAction.do?reference=STAT/12/96\&format $=$ HTML\&aged $=0 \&$ language $=$ EN\&guiLanguage $=$ fr.

6 UNHCR, Global Trends 2011: A Year of Crises (2012) 14, available at www.unhcr.org/4fd6f87f9.html. 
internal borders has been accompanied with an array of flanking measures and external border controls have been defined as a prominent security issue. As a process of construction, diffusion and institutionalization of norms, practices and shared convictions, the europeanization ${ }^{7}$ enables states to reinforce existing preventive and deterrent measures against asylum seekers. It results in the establishment of common norms and cooperation mechanisms making the system less attractive for asylum seeking. ${ }^{8}$ A similar trend is observed in North America, where the United States and Canada increasingly cooperate and harmonize their policies to stem unwanted migration. Canada also recently reformed its asylum system and adopted new norms directly inspired from European policies.

This chapter has two objectives. First, it analyses how the security prism has been used as a peculiar political frame to fashion asylum into a security issue without regard to its objective nature or to the actual threat. Secondly, it examines how securitization of asylum transforms the logic of domestic structures and public policies and how this process lowers refugee protection standards to the minimum possible and increases the vulnerability of asylum seekers.

After the first section which deals with the rationale behind the securitization of asylum, and particularly the political discourse labelling asylum seekers as a threat, the second and third sections analyse how this particular framework has legitimized international cooperation, repressive norms and policies against asylum seekers. The final section focuses on detention as a central tool of migration management.

\section{DEFINING ASYLUM AS A SECURITY ISSUE}

With the end of the Cold War, the concept of security has undergone a transformation. States, and specifically their external security agencies, which traditionally worked against a foreign enemy, have identified new threats, such as terrorism and international criminality, which coalesce in the image of the migrant. These threats affect the state from the inside,

7 Claudio Radaelli, 'Whither Europeanization: Concept Stretching and Substantive Change' (2000) 8 European Integration Online Papers 4; Idil Atak, L'européanisation de la lutte contre la migration irrégulière et les droits humains des migrants (Bruylant, 2011).

8 Council of the European Union, EU Action on Migratory Pressure: A Strategic Response, 8714/1/12 (Brussels, 23 April 2012). 
but are very often publicly defined as having their origin 'out there'. 9 Securitization arguments initially converged in stressing the security threats posed by 'criminal aliens'. By the mid-1990s, these arguments reflected concerns over border security in the face of growing irregular migration, increase in the numbers of asylum seekers and anti-immigrant policies. As a result, migration has increasingly been described and analysed in security terms. ${ }^{10}$ Several international and domestic initiatives have been taken to monitor and detain foreigners, be they migrants or asylum seekers, particularly those that find themselves at the borders.

Repressive policies mainly aim at fighting irregular migration, construed not only as a challenge to territorial sovereignty, but also as a threat to the welfare state and as a security risk. Asylum seekers have been conflated with irregular migrants since both categories tend to follow the same routes and use the same mechanisms for mobility, such as forged documentation or migrant smugglers. ${ }^{11}$ Arguing that asylum channels were abused by migrants, authorities adopted measures making domestic asylum systems harsher. ${ }^{12}$

The anxiety over asylum seekers was, in reality, anxiety over irregular immigration. Low success rates in asylum determination proceedings, partly the result of restrictive application of the 1951 Geneva Convention, were generally taken as proof of widespread abuse of the asylum system by irregular immigrants. But the merging of asylum and irregular immigration concerns also appeared to be directly encouraged by the nature of the refugee determination process itself. Lack of resources and bureaucratic inefficiency led to large backlogs, with the result that asylum applicants could expect to wait a number of years for their claim to be decided ... The failure of

9 Idil Atak and François Crépeau, 'National Security, Terrorism and the Securitization of Migration' in Vincent Chetail (ed.), Research Handbook on Migration and International Law (Edward Elgar Publishing, 2012); François Crépeau and Delphine Nakache, Controlling Irregular Migration in Canada: Reconciling Security Concerns with Human Rights Protection (IRPP Choices, 2006).

10 H.R. Friman, 'Migration and Security: Crime, Terror and the Politics of Order' in Ariane Chebel d'Appollonia and Simon Reich (ed.), Immigration, Integration and Security: America and Europe in Comparative Perspective (University of Pittsburgh Press, 2008) 130-44.

11 Stephen Castles, 'The Migration-Asylum Nexus and Regional Approaches' in Susan Kneebone and Felicity Rawlings-Sanaei (eds), New Regionalism and Asylum Seekers (Berghahn Books, 2007) 25, 26.

12 Anastassia Tsoukala, 'Turning Immigrants into Security Threats: A Multifaceted Process' in Gabriella Lazaridis (ed.), Security, Insecurity and Migration in Europe (Ashgate, 2011) 179. 
governments to remove unsuccessful asylum applicants did nothing to reduce the number of people with irregular migration status ... or to discourage an association of asylum with irregular migration in the public's mind. ${ }^{13}$

Based on flawed understandings of forced migration, the condition of the refugee is no longer a humanitarian or human rights issue - but a law enforcement and national security problem. ${ }^{14}$ Often, refugee determination was accelerated, appeals eliminated, legal aid and social protection reduced, detention increased, and legislative techniques such as "safe third country' lists and readmission agreements established. Asylum seekers were criminalized through such measures as criminalization of illegal entry or excessive penalties imposed for migrant smuggling. Criminalization is here understood not only in the narrow sense of 'making an activity illegal' by the imposition of penal sanctions on the migrant, or as reflecting the increased involvement of international criminal groups in irregular migration movements, but more broadly as encompassing the culture of suspicion and distrust surrounding the movement of asylum seekers, although, according to international law, refugees cannot be faulted for entering a host country irregularly. ${ }^{15}$

Political discourse plays a major role in the securitization of asylum in Europe and in Canada. Blurring the distinction between asylum seeker and irregular migrant, it often labels asylum seekers as a security threat. Securitization can be conceptualized as a speech act or a discursive process that moves issues from the realm of the political to a realm above politics. Any issue can become a security one, not necessarily because of the nature of the objective importance of the threats it poses but because it is presented as such. The securitizing speech act is set in a context of socially shared meanings framing the conditions for successful securitization. This process is largely dependent on an existing 'empowering audience' that legitimizes and reproduces the actor's securitizing frame. ${ }^{16}$ The successful securitizing actor must accordingly identify the needs and

13 Matthew J. Gibney, Outside the Protection of the Law: The Situation of Irregular Migrants in Europe, RSC Working Paper, No. 6 (Jesuit Refugee Service Europe, 2000) 4.

14 Sharon Pickering, 'Border Terror: Policing, Forced Migration and Terrorism' (2004) 16 Global Change, Peace and Security 215.

15 Ryszard Cholewinski, 'The Criminalisation of Migration in EU Law and Policy' in Anneliese Baldaccini, Elspeth Guild and Helen Toner (eds), Whose Freedom, Security and Justice? EU Immigration and Asylum Law and Policy (Hart Publishing, 2007) 301, 302.

16 Buzan, Waever and de Wilde, above note 2, at 24, 33; Thierry Balzacq, 'A Theory of Securitization: Origins, Core Assumptions and Variations' in Thierry 
sentiments of their audience, resorting to a security language that in some way resonates in the given socio-cultural environment. Whereas the overall perception of migrants in many societies tends to be negative, xenophobic discourse has been mainstreamed and is gaining increasing social acceptance. In numerous countries, extremist parties strive on an anti-immigration agenda and they set the tone of the political debate on migration issues. As a recent IOM report puts it, theory and research have had much less impact on policy formulation than political discourse, media reports and public opinion on the nature, purpose and socioeconomic impact of migration. By highlighting certain aspects of migration and not addressing others, by using particular language and certain kinds of rhetorical devices (such as analogies and metaphors), political actors not only provide people with some (carefully chosen) facts about migration, they also give them a sense of how that information should be interpreted. ${ }^{17}$

Stereotyped political representation contributes to the criminalization of asylum seekers and to what Didier Bigo describes as the establishment of an '(in)security continuum', transferring the 'illegitimacy' of crime and terrorism to migrants. ${ }^{18}$ The securitization discourse has been cemented by the fear that asylum claimants may be supporters of or potential contributors to terrorist activities. ${ }^{19}$ After the $9 / 11$ terrorist attacks, the UN and EU initiatives promoted the idea that 'the institution of asylum is a terrorist's refuge'.$^{20}$ For instance, the UN Security Council called upon states to take appropriate measures, before granting refugee status, for the purpose of ensuring that the asylum seeker has not planned, facilitated or participated in the commission of terrorist acts; and to ensure that refugee status is not abused by the perpetrators, organizers or facilitators of terrorist acts. ${ }^{21}$ The EU has also adopted

Balzacq (ed.), Securitization Theory: How Security Problems Emerge and Dissolve (Routledge, 2011) 13.

17 IOM, 'Communicating Effectively about Migration' in World Migration Report 2011 (2011) 3 and 17.

18 Didier Bigo, Polices en réseaux, l'expérience européenne (Presses de la Fondation Nationale des sciences politiques, 1996) 263.

19 Georgios Karyotis, 'The Fallacy of Securitizing Migration: Elite Rationality and Unintended Consequences' in Gabriella Lazaridis (ed.), Security, Insecurity and Migration in Europe (Ashgate, 2011) 13-25.

20 Asha Kaushal and Catherine Dauvergne, 'The Growing Culture of Exclusion: Trends in Canadian Refugee Exclusions' (2010) 23 IJRL 54, 58.

21 'Threats to international peace and security caused by terrorist acts', UNSC Res. 1373 (2001) para. 3(f) and (g); Council of the European Union, 
similar language, such as in the 1990 Convention applying the Schengen Agreement of 14 June $1985^{22}$ which connects migration and asylum with international criminality, including terrorism. ${ }^{23}$

The 2012 EU action paper on migratory pressure heavily focuses on the abuse of legal migration channels, and on the need to safeguard and protect free movement through the prevention of abuse of free movement rights by third country nationals. ${ }^{24}$ Düvell and Vollmer point out that the perceived magnitude of the threat justifies far higher surveillance resources for security agencies. In fact, irregular arrivals in the EU (151,000 persons in 2008) represents approximately 0.021 percent of all arrivals (714 million). There is therefore a clear gap between the demonstrated facts and the perceived threat which is propagated through a speech fraught with negative connotations and metaphors. The EU decisions frequently refer to states that are 'affected by large waves of immigration', 'flows of illegal migrants' and 'flood of asylum seekers'. ${ }^{25}$

In Canada, the treatment of Chinese migrants and Tamil asylum seekers who arrived by boat off the west coast in 1999, 2009 and 2010 offers a typical example of how migrants have been labelled as 'security threats' in political discourse which called into question Canada's immigration and refugee system. ${ }^{26}$ Although boat arrivals represented only 2 percent of the total number of asylum claims made in Canada in 2010 and despite the lack of evidence tying the passengers with terrorist

Extraordinary Council Meeting: Justice, Home Affairs and Civil Protection (Brussels, 20 September 2001).

22 Convention implementing the Schengen Agreement of 14 June 1985 between the Governments of the States of the Benelux Economic Union, the Federal Republic of Germany and the French Republic on the Gradual Abolition of Checks at their Common Borders [2000] OJ L239.

23 European Commission, Annex to the Communication on Common Principles for the Further Development of the Common Immigration Policy: A Platform for a New European Approach, Staff Working Document, Impact Assessment (2008) 21-2. See also Jef Huysmans, 'The European Union and the Securitization of Migration' (2000) 38 JCMS 751.

24 Council of the European Union, EU Action on Migratory Pressure: A Strategic Response, 8714/1/12 (Brussels, 23 April 2012).

25 See e.g., Council Regulation (EC) 377/2004 on the creation of an immigration liaison officers network, Art. 2 [2004] OJ L64; Frank Düvell and Bastian Vollmer, European Security Challenges, Improving EU and US Immigration Systems' Capacity for Responding to Global Challenges: Learning from Experiences, EU-US Immigration Systems 2011/1 (Robert Schuman Centre for Advanced Studies, European University Institute, 2011) 19.

26 Maggie Ibrahim, 'Securitization of Migration: A Racial Discourse' (2005) 43 International Migration 163. 
organizations, ${ }^{27}$ Canada's immigration and refugee system has been tightened (see below). Alarming political discourse justified the introduction of exceptional measures against 'smuggled' asylum seekers, including mandatory detention and a bar for recognized refugees from applying for permanent residence and sponsoring family members for five years. ${ }^{28}$ The Canadian Citizenship, Immigration and Multiculturalism Minister defined Canada's asylum system as 'broken' and presented the reform proposal as a means of preventing an abuse of the refugee system. Asylum claimants were portrayed as 'queue jumpers' to the detriment of 'immigrants who wait in line'. ${ }^{29}$ Claimants have also been presented as people taking advantage of Canada's generosity and costing taxpayers huge sums of money. ${ }^{30}$

Facing the anti-immigration discourse, there is generally no balanced and credible political counter-discourse, because of the absence of meaningful political mobilization in favour of asylum seekers. If misperceptions go unchecked, they result in marginalization and stigma of asylum claimants. ${ }^{31}$ In Europe and in Canada, political elites constructed threat perceptions and 'appropriate' responses that legitimized the 'voices of security'. ${ }^{32}$ Politicians' inflammatory declarations against migrants and brutal anti-immigration policies amalgamate all migration situations without distinguishing between complex fact patterns and individual circumstances. Heated debate on migration has contributed to racism and xenophobic sentiments in many countries, sometimes degenerating into rampages. Political elites managed to convince majorities that, in response to the threat embodied by asylum seekers, exceptional measures

27 Out of the 550 refugee claimants who arrived in Canada in 2010, only four people have been determined to be inadmissible to enter Canada and none for terrorism-related concerns.

28 Bill C-11, An Act to amend the Immigration and Refugee Protection Act and the Federal Courts Act (the Balanced Refugee Reform Act), Royal Assent 29 June 2010 and Bill C-31 Protecting Canada's Immigration System Act, Royal Assent 28 June 2012.

29 Citizenship and Immigration Canada, Balanced Reform Planned for Canada's Asylum System (2010), available at www.cic.gc.ca/english/department/ media/releases/2010/2010-03-30.asp.

30 Citizenship and Immigration Canada, Challenges Faced by Canada's Asylum System (2010), available at www.cic.gc.ca/english/department/media/ backgrounders/2010/2010-03-30a.asp.

31 IOM, 'Communicating Effectively about Migration' in World Migration Report 2011 (2011) 28.

32 Karyotis, above note 19. 
are needed, including increased international cooperation to stem unwanted migration.

\section{International Cooperation: Tracking and Intercepting Asylum Seekers}

International cooperation facilitates and makes more effective repressive migratory policies, ensuring the coordination and harmonization of states' actions and contributing to a high and uniform level of control on persons. Within the EU, several mechanisms of cooperation have been put into place since the 1980s within the framework of a 'common asylum system'. In this chapter, we will focus on two such mechanisms which allow us to draw comparisons with Canada: immigration agents posted abroad and surveillance of shared borders. These examples illustrate how interception measures are implemented beyond the border as well as at the border and what are their consequences on the right to asylum.

In the EU, the immigration liaison officers (ILOs) ${ }^{33}$ are representatives of Member States, posted abroad by the immigration services or other competent authorities with a view to contributing to preventing and combating irregular migration. The ILOs interact with the authorities in the host country on intelligence concerning migratory movements from or transiting through the host country, routes followed, modus operandi, methods used for falsifying documents, and assisting host countries in preventing unwanted migration. Supported by the secure web-based network ICONet, ILOs posted to the same country form local networks in which they exchange information, coordinate positions to be adopted in contacts with commercial carriers, attend joint specialized training courses and organize training sessions for consular officers of Member States posted in the host country, adopt common approaches as to methods of gathering information and establish contact with similar networks. The mandate of the ILOs network has been recently revised in order to allow Frontex (see below) to participate in its meetings. ${ }^{34}$

In Canada, migration integrity officers (MIOs) established in 1989 play a similar role in the interception of unwanted migrants, including asylum seekers. MIOs are Canadian Border Services Agency (CBSA) officers posted abroad whose mandate is 'protecting the integrity of the Canadian

\footnotetext{
33 Council Regulation (EC) 377/2004 on the creation of an immigration liaison officers network [2004] OJ L64.

34 Regulation (EU) 493/2011 of the European Parliament and of the Council of 5 April 2011 amending Council Regulation (EC) 377/2004 on the creation of an immigration liaison officers network [2011] OJ L141.
} 
border by identifying at the source high-risk travellers before they reach Canada'. ${ }^{35}$ MIOs carry out the task of stopping improperly-documented persons from boarding planes destined to Canada, gathering immigration intelligence, training airline staff and host country officials on Canadian documents, and liaising with local authorities. There are 56 MIOs located in 46 key foreign source and transit points around the world. In 2008-09, MIOs delivered training sessions to almost 12,000 individuals, including representatives from airlines and local law enforcement agencies, to help improve the ability of these partners to identify and intercept improperlydocumented travellers. MIOs are involved in the interdiction of approximately 5,000 people annually.

Joint surveillance of their shared border is part of states' securitization agenda. Frontex is emerging as a major player in Europe's bid in this regard. Founded in 2005, Frontex aims at improving the integrated management of the EU's external borders, combating irregular migration and promoting solidarity and mutual trust between the border guards of Member States and third countries. The EU agency plans, coordinates and conducts joint operations using Member States' staff and equipment at the external borders (sea, land and air). Frontex has created a pooled resource in the form of European Border Guard Teams and an extensive database of available equipment, which bring together specialist human and technical resources from across the EU. ${ }^{36}$ Maritime operations are by far the most important activity of Frontex to date. Several operations have been conducted targeting movements from West Africa to the Canary Islands, from Libya to Malta and Italy, or in the Aegean Sea. For instance, during the Arab Spring, a joint maritime operation entitled 'Hermes' has been conducted between February and September 2011, with the aim to control immigration from North Africa to Italy and Malta. Twenty thousand people were intercepted during the first five weeks of the operation.

In addition, Frontex facilitates operational cooperation between EU Member States by deploying Rapid Border Intervention Teams (Rabit) in order to provide a rapid response capacity to support Member States

35 CBSA, 'Migration Integrity Officers', Fact Sheet, available at www.cbsaasfc.gc.ca/media/facts-faits/030-eng.html.

36 Council Regulation (EC) 2007/2004 establishing a European Agency for the Management of Operational Cooperation at the External Borders of the Member States of the European Union [2004] OJ L349; Frontex, 'Mission and Tasks', available at www.frontex.europa.eu/about/mission-and-tasks. 
facing migratory pressure. ${ }^{37}$ The first Rabit operation has been organized upon the request of Greece at its land border with Turkey. From November 2010 to March 2011, experts in such areas as false document detection, clandestine entry, dog handling, border checks, as well as specialist interviewers, debriefers and linguists, were made available and dispatched by 26 Member and associated States during the four-month deployment, representing a total of 576 officers working around 19,000 man-days. Frontex has apprehended 11,809 irregular migrants. The Frontex Rabit Operation 2010 Evaluation Report does not mention the number of those who claimed asylum among irregular migrants intercepted. ${ }^{38}$

While fulfilling its mandate, Frontex liaises closely with other EU partners. For instance, during the Arab Spring in 2011, Europol provided 'risk assessment concerning the extent to which the volatile political situation in the region might be exploited by criminal or terrorist networks. It has also been providing assistance to Italy on the ground on Lampedusa, ensuring real-time access to criminal data-bases and assisting in the gathering of information.' ${ }^{39}$ Europol was initially established to support action by the Member States' police authorities and other law enforcement services and their mutual cooperation in preventing and combating serious crime. This agency has progressively been empowered to assist in devising and implementing measures against networks involved in migrant smuggling or human trafficking. The extension of Europol's mandate offers a typical example of how institutions which originally aim at combating terrorism and organized crime have been mobilized in migratory controls, thus amalgamating the different populations they traditionally targeted.

Frontex also cooperates with Canada. In October 2010, Canada's CBSA and Frontex signed an agreement to 'promote cooperation on issues of operational management and technical border security between

37 Regulation (EC) 863/2007 of the European Parliament and of the Council of 11 July 2007 establishing a mechanism for the creation of Rapid Border Intervention Teams and amending Council Regulation (EC) 2007/2004 as regards that mechanism and regulating the tasks and powers of guest officers [2007] OJ L 199.

38 Frontex, RABIT Operation 2010 Evaluation Report (2011), available at http://frontex.europa.eu/assets/Attachments_News/fer_rabit_2010_screen_v6.pdf.

39 European Commission, Schengen Governance: Strengthening the Area without Internal Border Control, COM(2011) 561 final (2011) 9. 
the two agencies to establish a lasting partnership', ${ }^{40}$ through the exchange of best practices and strategic information, staff training and the organization of joint operations.

The tightening of immigration controls is a major objective of the agenda of North American cooperation. The United States-Canada Shared Border Accord signed in 1995 included measures to improve cooperation between customs and immigration officials in both countries. Bilateral relationship has been strengthened after the terrorist attacks of 9/11 with a view to achieving unprecedented levels of control over migration. The Action Plan for Creating a Smart Border concluded on 12 December 2001 outlines several measures targeting asylum seekers, including developing common biometric identifiers; increasing security screening within refugee/asylum processing; exchanging information; negotiating a safe third country agreement (see below); coordinating visa policy; sharing advance passenger information and agreed-to passenger name records on flights between the two countries; establishing joint passenger analysis units at key international airports in Canada and the United States; and developing compatible immigration databases. The United States and Canada also decided to increase the number of Canadian and US immigration officers at airports overseas and undertake technical assistance to source and transit countries in order to enhance interception of asylum seekers. In 2011, Canada and the United States renewed their commitment to secure their shared border and adopted a joint action plan entitled 'Beyond the Border: A Shared Vision of Perimeter Security and Economic Competitiveness'. The two countries notably agreed to:

- improve mechanisms for cooperation in cross-border enforcement of the law and exchange of information and intelligence;

- establish a verification process in the two countries that could account for the whereabouts of persons;

- establish and verify the identity of foreign travelers bound for North America to improve decision-making on immigration and eligibility.

A centrepiece of this agreement is a joint entry-exit tracking system where the United States and Canada will effectively merge their land-border

40 'Frontex Signs Working Arrangement with Canada' (2011), available at www.frontex.europa.eu/news/frontex-signs-working-arrangement-with-canada$\mathrm{As} 1 \mathrm{qHj}$. 
screening efforts on their common frontier by recording and sharing details on people on the move. ${ }^{41}$

Ottawa and Washington are already conducting joint patrols or investigations along their shared land border, to carry out checks on public transport (buses, trains, ferries) and arrest persons without proper identification. These 'integrated teams of border police' (IBET) regroup the Royal Canadian Mounted Police, CBSA, US Customs and Border Protection/Office of Border Patrol, US Bureau of Immigration and Customs Enforcement and US.Coast Guard. ${ }^{42}$

The above-mentioned boat arrivals off the Canadian west coast in 2009 and 2010 (mostly Tamil asylum seekers from Sri Lanka who had boarded in Thailand) triggered an increasing cooperation of Canada with Southeast Asian states considered as both source and transit points for irregular migrants. Canada signed a security co-operation agreement within the framework of its 'Anti-Crime Capacity Building Program' which included training of police and immigration officers in Cambodia, Indonesia, Lao People's Democratic Republic, Malaysia, Thailand and Vietnam. ${ }^{43}$ An unknown number of Canadian officials have been sent to Thailand and are cooperating with local and regional authorities to intercept refugee ships. ${ }^{44}$

The implementation of international cooperation is enhanced by an arsenal of personal information databases and exchanges. For instance, Canada is a member of the Five Country Conference, a forum on migration security issues, alongside the United States, United Kingdom, Australia and New Zealand. Through bilateral agreements, these countries have agreed to a High Value Data Sharing Protocol, to share biometrics of non-citizens with each other for immigration purposes. The Canadian government introduced two new programs involving the sharing of sensitive personal information, such as fingerprints, from government to private-sector companies, and from government to government.

41 Beyond the Border: A Shared Vision of Perimeter Security and Economic Competitiveness (2011), available at http://actionplan.gc.ca/en/page/bbg-tpf/ perimeter-security-and-economic-competitiveness-action-plan.

42 Royal Canadian Mounted Police, 'Integrated Border Enforcement Teams (IBETs)', available at www.rcmp-grc.gc.ca/ibet-eipf/index-eng.htm.

43 Murray Brewster, 'Harper takes aim at human smuggling with cash and equipment for Thai police', Globe and Mail (Bangkok), 23 March 2012.

44 Jeff Davis, 'Smugglers dump Canada-bound Tamils in Togo', Gazette (Montreal), 31 January 2012. 
Canada is sharing 3,000 fingerprints each year with each partner, covering mostly asylum claimants. ${ }^{45}$

Information sharing is also among the EU's priorities. Several databases such as the Schengen Information System and EURODAC (a database of asylum seekers' fingerprints whose purpose is the identification of the Member State responsible for assessing an asylum claim, see below) have been established to collect and share personal and biometric information on foreigners, including asylum seekers. In the near future, the European Border Surveillance System (EUROSUR) will ensure sharing of operational information among Member States' authorities responsible for border surveillance and Frontex. ${ }^{46}$

Policies implemented within the framework of such international cooperation have negative consequences on asylum. Security at the border may need to be improved, but it is unfair to represent the migration control system as porous, thus justifying stricter controls on the entry of refugees to destination countries. Most of these measures do not aim at protecting refugees better: they rather ensure that fewer persons will be able to reach the border and ask for protection. States breach their human rights obligations by externalizing their borders to third countries without ensuring that such countries have the will and the means to carry out the same level of human rights protection in favour of migrants. International principles such as the right to leave a country, the right to claim asylum ${ }^{47}$ and the principle of non-refoulement may not be guaranteed if migrants are intercepted and sent back.

The extension of enforcement mechanisms beyond state territory does not carry with it a clear obligation to ensure international protection for those who need it. By using extra-territorial mechanisms, states can pretend that they are free from the international and domestic legal constraints and scrutiny they face when migrants arrive on their territory. States are not, however, beyond the bounds of responsibility. The International Law Commission's Articles on Responsibility of States for Internationally Wrongful Acts provide that responsibility ultimately

45 Kristen Shane, 'Biometrics programs prompt privacy concerns', Embassy (Ottawa), 11 January 2012.

46 European Commission, Smart Borders: Options and the Way Ahead, COM 2011/0680 final (2011); European Commission, A Dialogue for Migration, Mobility and Security with the Southern Mediterranean Countries, COM 2011/ 292/3 (2011).

47 Universal Declaration of Human Rights, GA Res. 217A(III), UN Doc. A/810 (1948) 71, Art. 14; Charter of Fundamental Rights of the EU, Art. 18 [2000] OJ C364/1. 
hinges on whether the relevant conduct can be attributed to that state and not whether it occurs within the territory of the state or outside it. ${ }^{48}$ Applicability of human rights law is further underlined by the jurisprudence of the UN Human Rights Committee and regional human rights systems. ${ }^{49}$ In its Hirsi Jamaa and others $v$ Italy judgment concerning the interception by the Italian authorities of asylum seekers in the Mediterranean, their transfer to Italian military vessels and their forced removal to Libya, the European Court of Human Rights (ECtHR) held that the events giving rise to the alleged violations fall within Italy's 'jurisdiction': in the period between boarding the ships of the Italian armed forces and being handed over to the Libyan authorities, the applicants were under the continuous and exclusive de jure and de facto control of the Italian authorities. ${ }^{50}$ The Court further held that returning migrants to Libya without examining their case exposed them to a risk of illtreatment and amounted to a collective expulsion.

International cooperation with a view to intercepting migrants is contrary to the international human rights principles which require states to take no action to prevent people leaving the country where they fear persecution. In December 2004, the UK House of Lords held that a preclearance immigration control scheme at Prague airport, conducted pursuant to an agreement with the Czech Republic, preventing Czech citizens of Roma origin from travelling to the United Kingdom, constituted direct racial discrimination. ${ }^{51}$ International cooperation also violates the principle of non-refoulement enshrined in Article 33 of the 1951 Refugee Convention when intercepted asylum seekers are sent back to their place of departure or to third countries without having the possibility to claim asylum. Asylum seekers who are intercepted beyond national borders often have no access to an effective asylum procedure, to an effective opportunity to challenge their return, ${ }^{52}$ to procedural guarantees

48 International Law Commission, Draft Articles on Responsibility of States for Internationally Wrongful Acts, Report of the International Law Commission on the work of its 53rd session, Official records of the General Assembly, 56th Sess., Supp. no. 10 [2001] (A/56/10, chap. I.V.E.1.).

49 See e.g., Haitian Interdiction v United States, Report 51/96, Case no. 10.675, Decision as to the Merits of 13 March 1997 [1996] Inter-American Commission on Human Rights Report 598.

50 Hirsi Jamaa and others v Italy (App. no. 27765/09), ECtHR, judgment of 23 February 2012, para. 81.

$51 \quad R$ v Immigration Officer at Prague Airport, ex parte European Roma Rights Centre [2004] UKHL 55.

52 Gebremedhin [Geberamadhien] v France (App no. 25389/05), ECtHR (2007-II) para. 66. 
including the right to information, to a legal counsel, to an interpreter or to legal aid during interception operations. ${ }^{53}$ Moreover, there are important human rights implications in the collection, processing and sharing of a person's unique physical identifiers through biometric technology, including the right to privacy and the fight against discrimination. Certain ethnic groups have been deliberately targeted by immigration controls. People fleeing persecution may experience such procedure as a retraumatization. Asylum seekers may be stigmatized by blurring the boundaries between migration and police databases. Such databases are implemented with limited public debate on their necessity, proportionality and fundamental rights implications, and with little capacity of targeted individuals to actually access the personal information they contain. ${ }^{54}$

\section{Securitizing by Norms: 'Safe Country’ Criterion}

The culture of distrust against asylum seekers has been fueled by the adoption of stigmatizing standards. States have tightened the criteria for granting refugee status, with a view to limiting the number of persons granted asylum, deterring 'abuse' and reducing the 'burden' of 'manifestly unfounded' asylum claims. The 'safe country' notion is part of this process.

The 'safe third country' criterion allows the return of an asylum seeker to a third country - often a transit country - that will be responsible for processing her claim. As the state of return is considered as 'safe', the removal would involve no risk of refoulement and would be consistent with state obligations under international refugee law. The criterion was first implemented by some European states during the 1980s. It was subsequently adopted by the EU to ensure among its Member States a better sharing of responsibility and costs in processing asylum claims. The Dublin Convention of 1990 sets out the criteria for determining the Member State responsible for examining an asylum application lodged in one of the Member States. It is based on the assumption that all EU Member States are safe. The aim is also to deal with multiple demands made by a same claimant, thus avoiding 'forum shopping'. The 2003

53 MSS v Belgium and Greece (App. no. 30696/09), ECtHR, judgment of 21 January 2011, para. 388.

54 Ben Hayes, Borderline: EU Border Surveillance Initiatives: An Assessment of the Costs and its Impact on Fundamental Rights (Heinrich Böll Stiftung, 2012) 9 . 
Dublin II Regulation ${ }^{55}$ sets out a list of 'objective' criteria in the determination of the responsible Member State, including the case of unaccompanied minors, the family unit, etc. The state which the asylum seeker entered first still remains the one most often responsible.

Similar developments can be observed in North America. In December 2002, Canada and the United States signed a Safe Third Country Agreement ${ }^{56}$ which allows each country to send back all the asylum seekers who have reached its territory by way of the other. The rule applies only at a land port of entry.

The concept of 'safe country of origin' allows returning a refugee claimant to her home state. The rationale behind it is that citizens of countries deemed to be safe are in theory not at risk of persecution. It is presumed that their claim doesn't need a high scrutiny and can be processed through accelerated procedures.

The criterion has been systematically implemented by the EU Member States since the 1990s. In the United Kingdom, for instance, claims of 'safe' country citizens are considered as 'clearly unfounded'. The notion provides a basis to 'filter' asylum claims through accelerated procedures. Similarly, in France, claimants from safe countries of origin are submitted to a 'priority procedure' where their claims are fast-tracked.

Both 'safe country of origin' and 'safe third country' criteria are part of EU law. Council Directive 2005/85/EC on minimum standards on procedures in Member States for granting and withdrawing refugee status ('Procedure Directive') ${ }^{57}$ allows Member States to designate a country as 'safe', unless the claimant presents serious counter-indications. The Directive also encourages the establishment of common criteria for designating third countries as safe countries of origin (Preamble paragraphs 17 and 18, Articles 27 and 30). In Canada, the 'designated country of origin', modelled on its European counterpart, is one of the most controversial measures recently introduced into the domestic asylum

55 Council Regulation (EC) 343/2003 establishing the criteria and mechanisms for determining the Member State responsible for examining an asylum application lodged in one of the Member States by a third country national [2003] OJ L50.

56 Agreement between the Government of Canada and the Government of the United States of America for cooperation in the examination of refugee status claims from nationals of third countries signed on 5 December 2002, available at www.cic.gc.ca/english/department/laws-policy/safe-third.asp.

57 Council Directive 2005/85/EC of 1 December 2005 on minimum standards on procedures in Member States for granting and withdrawing refugee status [2005] OJ L326/13. 
system. The Minister of Citizenship and Immigration can designate a country as a 'safe country of origin' and then impose several limitations on the rights of refugee claimants originating from that country.

In Canada, asylum claims by nationals of designated states will soon be considered to be 'manifestly unfounded'. They will face shorter timelines for the preparation of their first interview and hearing. Asylum claimants from a 'designated safe country of origin' would not be able to appeal a negative decision to the Refugee Appeal Division, and would not benefit from an automatic stay of removal during judicial review proceedings. ${ }^{58}$

The implementation of the 'safe country' concept results in serious human rights violations. The Canada-United States Safe Third Country Agreement led to hundreds of refugee claimants being summarily sent back from Canada to the United States, where many were detained and/or deported. Non-governmental organizations and the UNHCR have questioned the basic premise that the United States is a safe country for all asylum seekers. Certain US practices are of great concern, including detention procedures, the expedited removal process, the one-year time limit to file a claim in the United States, the more restrictive interpretation of the refugee definition, etc. Moreover, the United States systematically detains unaccompanied minors, whereas in Canada they are protected according to their 'best interest'. ${ }^{59}$ In a recent case concerning the return, under the Safe Third Country Agreement, of three refugee claimants to the United States where they were detained in an ordinary jail and deported to their countries of origin, the Inter-American Commission on Human Rights held that Canada violated its human rights obligations, mainly for failing to provide individualized review of their asylum claims. ${ }^{60}$

Moreover, the designation of a state as 'safe' is not based on objective criteria, but on political considerations. The executive holds unilateral power to list countries as 'safe'. This process politicizes the refugee system and substantially increases the risk that decisions will be influenced by foreign policy considerations, including trade and investment. The 'safe country' concept is contrary to the principle of individual assessment of each asylum claim on its own merits. In many countries

58 Bill C-11, Balanced Refugee Reform Act 2010, Section 109.1; Bill C-31 Protecting Canada's Immigration System Act, Section 110(2)(a).

59 Baker v Canada (Ministry of Citizenship and Immigration) [1999] 2 SCR 817.

60 John Doe et al. v Canada (Report No. 78/11, Case 12.586), InterAmerican Commission on Human Rights (IACHR), decision of 21 July 2011. 
that seem 'safe', there can be problems of persecution on certain grounds or for certain people. In addition, a two-tier system which denies some claimants access to an appeal based on their nationality is discriminatory and contrary to the non-discrimination clause of Article 3 of the 1951 Refugee Convention.

Experience has shown that the implementation of the 'safe third country' criterion substantially transforms the access to asylum procedure and the assessment of claims. Claimants face a high risk of denial of fair process which in turn may lead to their refoulement. The right to an effective remedy is negatively affected. Fast-tracking of claims results into poorer procedural safeguards (difficulties in accessing a lawyer or an interpreter, reduction of legal aid, tight timelines to submit evidence, etc.) and to increased detention of asylum seekers. Due to reduced procedural guarantees, especially when detained, it is extremely difficult for claimants to rebut the presumption of safety. ${ }^{61}$

The 'safe country' criterion penalises vulnerable asylum seekers such as victims of torture or rape, and persons persecuted on the basis of their sexual orientation, who often need more time to present evidence necessary to substantiate their claims.

These concerns have been echoed by numerous court decisions both at the European and national level against implementation of safe country criterion. For instance, in France and the United Kingdom, courts challenged its compatibility with the non-refoulement principle, the right to liberty, to respect for one's family or private life, to an effective remedy, to legal counsel, to a stay of removal pending the appeal decision, as well as excessive detention time during the procedure. ${ }^{62}$ In a case concerning an Afghan national who irregularly entered Europe through Greece, before introducing an asylum claim in the United Kingdom, the European Court of Justice (ECJ) stated that the transferring Member State is obliged to assess compliance of the receiving Member

61 Commissaire aux droits de l'Homme du Conseil de l'Europe, Rapport sur le respect effectif des droits de l'Homme en France suite à sa visite du 5 au 21 septembre 2005 (2006) paras 244-7.

$62 R v$ Secretary of State for the Home Department, ex parte Maria Carvelho [1996] Imm. AR 435; $R v$ Secretary of State for the Home Department, ex parte Adan; $R v$ Secretary of State for the Home Department, ex parte Aitseguer [2001] 2 WLR 143; Ahmadi v Secretary of State for the Home Department [2005] EWCA Civ 38; Conseil d'État, 26 August 2010, no. 342683 CE, 20 May 2010, no. 339478; Conseil d'Etat, référés, 11 October 2011, nos 353002 and 353006; Tribunal administratif, Paris, réf., 26 January 2011, Negmatullah X; Tribunal administratif, Paris, réf., 17 July 2009, no. 0911567/9. 
State with the Charter of Fundamental Rights and the EU asylum acquis. Member States may not transfer asylum seekers to the Member State responsible for their application under the Dublin II Regulation where they cannot be unaware that systemic flaws in the asylum procedure and in the reception conditions of asylum seekers in that Member State amount to substantial grounds for believing that the asylum seeker would face a real risk of ill-treatment. ${ }^{63}$ The ECJ also found that the presumption underlying the Dublin II Regulation - all EU Member States are deemed to be safe for asylum seekers - must be regarded as rebuttable. In MSS v Belgium and Greece, the ECtHR condemned Belgium for exposing an Afghan asylum seeker to inhuman and degrading treatment by sending him back to Greece under the Dublin II Regulation. ${ }^{64}$

The implementation of the 'safe country' notion proves to be ineffective and counterproductive. It creates secondary asylum movements and actually increases, rather than reduces, the situation of 'refugees in orbit'. ${ }^{65}$ The appropriate way to cope with unfounded claims is to have an effective refugee status determination system with proper resources. Other solutions necessarily put states in violation of their domestic and international human rights protection obligations.

In the EU, the humanitarian crises created in some Member States such as Greece and Malta by extremely poor reception conditions, lack of adequate legal remedies and of asylum seekers' lengthy detention have highlighted the inefficiency of the Dublin system. Several states have suspended transfers to Greece under the Dublin II Regulation. Such suspension does not offer a durable solution. The system is in fact based on the flawed premise that all EU Member States have common standards of protection and capacity to process and host asylum seekers fairly. In addition, the EU lacks solidarity mechanisms to enable Member States to support each other better in dealing with challenges of asylum seekers' influx. These problems have been acknowledged by the EU, which has tried to recast the Dublin II Regulation ensuring higher protection standards for asylum seekers. In light of recent EU developments, it is difficult to understand why Canada has chosen to implement a 'safe country of origin' concept modeled on the European system.

63 NS v United Kingdom (C411/10 and C493/10) [2011] OJ C49/8.

64 MSS v Belgium and Greece (App. no. 30696/09), ECtHR, judgment of 21 January 2011.

65 Gretchen Borchelt, 'The Safe Third Country Practice in the European Union: A Misguided Approach to Asylum Law and a Violation of International Human Rights Standards' (2002) 33 Colum. Hum. Rts L Rev. 473, 502. 


\section{SYSTEMATIC DETENTION OF ASYLUM SEEKERS: A MIGRATION MANAGEMENT TOOL}

States increasingly rely on detention of asylum seekers as a migration management tool. Detention has become a widespread administrative practice of deterrence. For instance, 363,064 immigrants were detained in the United States in 2010, 52.8 percent more than the 2005 level. Likewise, before the 1990s, British authorities rarely detained aliens for migration purposes. The first permanent detention centre was established in November 1993. About 25,900 people entered immigration detention in the United Kingdom's 13 facilities in 2010.66 In France, in 2009, some 35,000 aliens were detained in some 20 'centres de rétention administrative' and around 200 smaller administrative detention facilities. Waiting zones ('Zones d'attente') are another detention regime for foreigners, including asylum seekers, asking to be admitted in France at a border point. Established in 1992, there are now more than 50 such zones in France. In Canada, the three immigration holding centres have a total capacity of 299 detainees, although this is set to increase soon by some 30 percent. ${ }^{67}$ Detention of asylum seekers has also become common in transit and new destination countries. In Israel, a vast detention complex will be constructed in the Negev desert with the capacity to hold upwards of 11,000 persons and will become the world's largest holding facility for asylum seekers. Detention has become systematic in third countries geographically situated at the periphery of the EU's external borders and that have conditional relations with the EU. ${ }^{68}$ In Turkey, until 2000, there was no established policy of detaining asylum seekers who were registering with the police. The situation changed drastically with the opening of the EU membership negotiation process. The 2004 Plan of Action on

66 Migration Information Source, Immigrant Detention under Scrutiny in Australia, United Kingdom, and United States (2011), available at www.migrationinformation.org/Feature/display.cfm?ID=868.

67 Delphine Nakache, The Human and Financial Cost of Detention of Asylum-Seekers in Canada (2011), available at www.socialsciences.uottawa.ca/ edim/eng/documents/1.pdf; Canada Border Services Agency, CBSA Detentions and Removals Programs: Evaluation Study (2010), available at http://cbsaasfc.gc.ca/agency-agence/reports-rapports/ae-ve/2010/dr-rd-eng.html.

68 'UN Special Rapporteur on the human rights of migrants concludes second country visit in his regional study on the human rights of migrants at the borders of the European Union: visit to Turkey' (29 June 2012), available at www.ohchr.org/EN/NewsEvents/Pages/DisplayNews.aspx?NewsID=12307\& LangID $=\mathrm{E}$. 
Asylum and Migration elaborated upon the request of the EU provides the construction of 'Centres for the reception and accommodation of asylum seekers and refugee guesthouses', built with the EU's substantial financial support from the pre-accession funds. In 2008, 46,609 irregular migrants, most of them asylum seekers, were reported detained in unacceptable conditions. ${ }^{69}$ The EU also enhances its Members States' capacity to detain asylum seekers: between 2007 and 2011, Greece received $€ 119$ million, and a further $€ 44.7$ million is foreseen for 2012 towards improving border management, in particular at the GreeceTurkey land border, including by the construction of several new detention centres. ${ }^{70}$

The majority of asylum seekers are detained because of concerns about their identity or the possibility that they might not appear for a hearing. Alternative non-custodial measures are not well-developed and usually not even envisaged in destination countries. Detention has also become an integral part of asylum claims' processing. States increasingly detain asylum seekers upon their arrival despite the penal immunity clause of Article 31 of the 1951 Refugee Convention. ${ }^{71}$ Special fast-track procedures are associated with systematic detention. ${ }^{72}$ In Canada, under the above-mentioned Bill C-31, asylum seekers arriving in groups of two or more will face mandatory detention for up to 12 months.

Yet, systematic recourse to detention of asylum seekers violates the international obligation to resort to detention only after a careful examination of the necessity of deprivation of liberty in each individual case. The right to liberty and security of the person and the prohibition of arbitrariness require that detention be, in each case, prescribed by law, necessary, reasonable and proportional to the objectives to be achieved..$^{73}$

69 Insan Haklari Dernegi, 2008, Türkiye insan haklari ihlalleri raporu (2009), available at www.ihd.org.tr/images/pdf/IHD_2009_YILI_INSAN_ HAKLARI_IHLALLERI_RAPORU.pdf.

70 European Commission, Third Annual Report on Immigration and Asylum, $\operatorname{COM}(2012) 250$ final (Brussels, 2012) 61.

71 Article 31.1.

72 Independent Chief Inspector of the UK Border Agency, Asylum: A Thematic Inspection of the Detained Fast Track (2011), available at http:// icinspector.independent.gov.uk/wp-content/uploads/2012/02/Asylum_A-thematicinspection-of-Detained-Fast-Track1.pdf.

73 See eg, the Council of Europe's Twenty Guidelines on Forced Return CM(2005)40 (2005). See also Art. 9(1) of the International Covenant on Civil and Political Rights; Art. 16(4) of the International Convention on the Protection of the Rights of All Migrant Workers and Members of their Families; Art. 5(1)(f) 
Asylum seekers in detention are frequently denied, by law or for lack of resources, key procedural safeguards, such as the right to be informed of the reasons of their arrest, prompt access to a lawyer, to interpretation/ translation services, to necessary medical care, to means of contacting family or consular representatives, and to ways of challenging detention. ${ }^{74}$

In several countries, including the United Kingdom, there is no automatic judicial review of the legality of the deprivation of liberty. In Canada, Bill C-31 provides for a review of detention within 14 days and then after six months (review after one year was originally proposed). This is still a radical change from the current system, under which anyone detained gets independent review of their detention within 48 hours. In a 2008 decision dealing with security detention of foreign nationals, the Supreme Court of Canada held that people should not be arbitrarily detained, and that the review of any detention should take place as quickly as possible. ${ }^{75}$

In its judgment in MSS v Belgium and Greece, the ECtHR stated that asylum seekers should be entitled to extra guarantees in detention since they can be seen as particularly vulnerable. ${ }^{76}$ Moreover, in IM v France, the Court held that the detention of asylum applicants may undermine their ability to substantiate their asylum account and that an 'effective remedy' requires an appeal with suspensive effect against refoulement in order to prevent irreparable harm, enough time to prepare the appeal and effective legal assistance and interpretation. ${ }^{77}$

Domestic human rights principles and international law provide that the duration of administrative detention of an asylum seeker should be as short as possible, and detention should not continue beyond the period

of the European Convention on Human Rights; Vélez Loor v Panama, InterAmerican Court of Human Rights, judgment of 23 November 2010.

74 Report of the United Nations Special Rapporteur on the Human Rights of Migrants, François Crépeau, A/HRC/20/2420 (2012).

75 Charkaoui $v$ Canada (Citizenship and Immigration) (23 February 2007) 1 SCR 350, 2007 SCC 9 (Supreme Court of Canada).

76 MSS v Belgium and Greece (App. no. 30696/09), ECtHR, judgment of 21 January 2011; Standing Committee of Experts on International Immigration, Refugee and Criminal Law (Meijers Committee), Detention Provisions in the Recast Proposals for the Reception Conditions Directive and the Dublin Regulation and the Right to a Remedy with Suspensive Effect (2012) 2, available at www.statewatch.org/news/2012/jun/meijers-committee-reception.pdf.

77 IM v France (App. no. 9152/09), ECtHR, judgment of 2 February 2012, para. 151; MSS v Belgium and Greece (App. no. 30696/09), ECtHR, judgment of 21 January 2011, para. 388. 
for which the state can provide appropriate justification. The principle of proportionality requires that detention has a legitimate aim, which would not exist if there were no longer a real and tangible prospect of removal. Nevertheless, in many countries including Canada, the United States and the United Kingdom, there is no time-limit on detention. ${ }^{78}$ Also, longterm administrative detention of migrants, sometimes over a year, is frequent..$^{79}$ Length of time in detention increased in 2009-10 in Canada for all detained asylum seekers. ${ }^{80}$ The EU Return Directive allows Member States to keep in detention a third country national who is the subject of return procedures in order to prepare the return and/or carry out the removal process for up to six months, with a possible extension to 18 months in case of lack of cooperation of the third country national, or delays in obtaining the necessary documentation from third countries. ${ }^{81}$ The incorporation of these provisions into domestic law has resulted in a general increase in the maximum length of detention allowed in the EU Member States.

The conditions of detention are usually not appropriate. Asylum seekers are detained in a wide range of places, including prisons, police stations, unofficial migration detention centres, military bases, private security company compounds, disused warehouses, airports, ships, etc. These detention facilities are placed under the responsibility of many different public authorities, at local, regional or national level, which makes it difficult to ensure the consistent enforcement of standards of detention. In the United States, asylum seekers are detained in federal facilities as well as 350 local jails (for half of them) and private prisons, often without having been properly represented. ${ }^{82}$ In addition to dedicated detention facilities, British authorities hold asylum seekers in places such as military bases, correctional institutions and airports.

78 Nasrulloyev v Russia (App. no. 656/06), ECtHR, judgment of 11 October 2007, paras 73-7; Ismailov v Russia (App. no. 2947/06), ECtHR, judgment of 24 April 2008, para. 140; Working Group on Arbitrary Detention, Deliberation no. 5, A/HRC/13/30, para. 61.

79 See $A$ v Australia, Communication No. 560/1993, UN Doc. CCPR/C/59/ D/560/1993 (30 April 1997) para. 9.4.

80 Nakache, above note 67.

81 Directive 2008/115/EC of the European Parliament and of the Council on common standards and procedures in Member States for returning illegally staying third country nationals (2008) OJ L348/98.

82 Human Rights First, U.S. Detention of Asylum Seekers: Seeking Protection, Finding Prison (New York, 2009), available at www.humanrightsfirst.org/ wp-content/uploads/pdf/090429-RP-hrf-asylum-detention-report.pdf. 
According to the Independent Monitoring Board, 15,000 people (including 3,000 children) were held in 2011 at Heathrow airport in 'disgusting and degrading' conditions for hours, and in some cases for over a day. ${ }^{83}$ In Canada, the immigration holding centres operate as medium-security prisons, with fences equipped with razor wire, central locking door systems, security guards and surveillance cameras. ${ }^{84}$ During the past years, the use of provincial prisons for immigration detention purposes has steadily increased (35 percent in 2010-11), even for those considered low risk. ${ }^{85}$

Asylum seekers are sometimes detained in unacceptable substandard conditions in overcrowded facilities with poor hygiene, limited or no sanitation, sexual and physical abuse and inadequate medical care. ${ }^{86}$ Detention conditions violate the requirement that all persons deprived of their liberty must be treated with humanity and with respect for the inherent dignity of the human person. ${ }^{87}$ As a consequence, there were several instances of desperate violence in migration detention centres, such as suicide attempts, self-mutilation, hunger strikes, rioting, manifestations of violence against staff and arson: such instances could probably be considerably reduced if effective, frequent and independent monitoring of the detention facilities was implemented, including secure and accessible mechanisms for receiving complaints by migrant detainees.

Privately run migrant detention centres pose particular difficulties in terms of monitoring. Several human rights organizations expressed

83 'Children room at Heathrow is "disgraceful", Sky News, 14 May 2012, available at http://news.sky.com/story/17985/childrens-rooms-at-heathrowdisgraceful.

84 Janet Cleveland, Bill C-4: The Impact of Detention and Temporary Status on Mental Health of Asylum Seekers (2012), available at www.global detentionproject.org/fileadmin/Canada_cleveland.pdf.

85 Global Detention Project, Canada Detention Profile (2012), available at www.globaldetentionproject.org/countries/americas/canada/introduction.html.

86 Joe Nimmo, Haslar Failing its Most Vulnerable Inmates: Report (12 October 2011), available at www.portsmouth.co.uk/news/law-and-order/haslarfailing-its-most-vulnerable-inmates-report-1-3140418; “This is hell”: Romania horrendous detention conditions', Statewatch news online (2012), available at www.statewatch.org/news/2012/apr/02romania.htm; Marie Martin, 'We are not animals: concern intensifies over detention of migrants in Europe', Statewatch analysis (2012), available at www.statewatch.org/analyses/no-182-eu-detentioncentres.pdf; International Commission of Jurists, Not Here to Stay, Report of the ICJ on its Visit to Malta on 26-30 September 2011, available at http:// documents.icj.org/ICJMaltaMissionReport-Final.pdf.

87 ICCPR, Art. 10.1. 
concern about the increasing privatization of detention facilities. In several countries, private security firms dominate detention, transport and escort services for asylum seekers, displacing politically accountable public institutions. According to the UN Human Rights Committee, 'the contracting out to the private commercial sector of core State activities which involve the use of force and the detention of persons does not absolve a State party of its obligations under the Covenant' ${ }^{88}$ Yet in many countries, and especially in the United States, the United Kingdom and Australia, poor conditions and ill-treatment of detainees have been linked with private firms not meeting government standards of practice. ${ }^{89}$

Detention can be particularly damaging to asylum seekers with particular protection needs, such as children, unaccompanied older persons, persons with a physical disability, persons living with HIV/AIDS, pregnant women, victims of trafficking, torture victims, and persons with severe mental health problems. Such vulnerable persons are routinely held in detention despite the general acceptance that detention seriously harms their psychological capacities. Moreover, clinical symptoms related to severe depression, anxiety, post-traumatic stress disorder and suicidal ideation are all significantly correlated to detention, and especially prolonged periods of detention..$^{90}$

Detention of children is particularly worrying. Among the Tamil asylum seekers who arrived off Canadian shores in June 2010, there were 49 children, including six unaccompanied minors. All of them were detained upon arrival for lengthy periods, some lasting up to seven months. Researchers noted a range of disturbances associated with detention, including disruptive conduct, nocturnal enuresis, separation

88 See Cabal and Pasini v Australia, Communication No. 1020/2001, UN Doc. CCPR/C/78/D/1020/2001 (7 August 2003) para. 7.2.

89 Migration Information Source, above note 66; Emma Ginn, Outsourcing Abuse: The Use and Misuse of State-sanctioned Force during the Detention and Removal of Asylum Seekers (Birnberg Peirce and Partners, Medical Justice and the National Coalition of Anti-deportation Campaigns, 2008); Nina Bernstein, 'Companies use immigration crackdown to turn into profit', New York Times, 28 September 2011.

90 Report of the United Nations Special Rapporteur on the Human Rights of Migrants, François Crépeau, A/HRC/20/2420 (2012) paras 43-6; Medical Justice, The Second Torture: The Immigration Detention of Torture Survivors (2012), available at www.medicaljustice.org.uk/images/stories/reports/second torturereport.pdf. 
anxiety, sleep disturbance, nightmares and impaired cognitive development. ${ }^{91}$ Despite these findings, Bill C-31 further extends the scope of child detention. Children under 16 whose parents are subject to mandatory detention will either be informally held with their parents or separated from their parents and placed in foster care. ${ }^{92}$ In 2008, France deported one-third of the 1,000 unaccompanied migrant children who arrived at Roissy-Charles-de-Gaulle airport, detaining them in a transit zone in the same facilities as adults. ${ }^{93}$ In many countries, it is common that unaccompanied child asylum seekers are detained because they are wrongly classified as adults. ${ }^{94}$

Such state practices are contrary to domestic and international human rights standards. The principle should be freedom, detention being the exception. Moreover, vulnerable persons should only be held in exceptional circumstances, under conditions that will not adversely affect their health and wellbeing. In addition, there must be regular follow-up, support by skilled personnel, access to adequate health services, medication and counselling. ${ }^{95}$ These principles are underlined in numerous court judgments. For instance, the ECtHR pointed to the extremely vulnerable situation of a nine-year-old unaccompanied minor and ruled that her detention for three months demonstrated a lack of humanity to a degree that amounted to inhuman treatment. ${ }^{96}$

The Court came to the same conclusion about the detention of children accompanied by their mother, underlining the devastating effects detention has on the mental health of children who were vulnerable because of their age and their personal history. The Court also ruled that detention

91 Rachel Kronick, Cécile Rousseau and Janet Cleveland, 'Mandatory Detention of Refugee Children: A Public Health Issue?' (2011) 16(8) Paediatrics and Child Health 66.

92 Applied Research Centre, Shattered Families (2011), available at http:// arc.org/shatteredfamilies.

93 'Child asylum seekers get $£ 1 \mathrm{~m}$ Home Office compensation', BBC News, 18 February 2012; Alan Travis, "UK Border Agency "detaining children" at Heathrow', Guardian, 14 May 2012.

94 Human Rights Watch, France: Abolish Limbo for Migrant Children (2009).

95 Report of the United Nations Special Rapporteur on the Human Rights of Migrants, François Crépeau, A/HRC/20/2420 (2012) paras 38-41.

96 Mubilanzila Mayeka and Kaniki Mitunga v Belgium (App. no. 13178/0), ECtHR, judgment of 12 October 2006; Muskhadzhiyeva and others v Belgium (App. no. 41442/07), ECtHR, judgment of 19 January 2010. 
for a very long period in a centre for adults is inappropriate for children, amounting to inhuman and degrading treatment. ${ }^{97}$

In the EU, the detention provisions in the Dublin II Regulation and Reception Conditions Directive ${ }^{98}$ are arguably at odds with the recent case law of the ECtHR concerning the detention of foreign children, as it should be provided that not only the asylum applicant who is detained, but also the children who are accompanying her in detention must have access to speedy judicial review of their detention. ${ }^{99}$ The weaknesses of the EU asylum system have been acknowledged and a reform process has been launched with a view to ensuring a more harmonized and coherent reception system.

Repressive measures are not very effective deterrence means anyway. Mandatory detention and delayed family reunification don't deter asylum seekers from arriving at borders. Australia introduced such tough measures in 1999: nonetheless, the number of 'unauthorized arrivals' has multiplied to more than 6,000 last year. ${ }^{100}$

Immigration detention comes with a financial cost. In the United States, the current system costs the federal government US\$2.4 billion annually. In 2010, the UK government admitted the cost of one bed per day in a detention centre to be around £120. Using these numbers, Oxford University projected the costs for operating one detention centre in the United Kingdom to be approximately $£ 8.5$ million per year. In France, the cost of detaining one person per day is estimated to be $€ 355$ in 2005; and in 2008, France spent $€ 533$ million for the detention and expulsion of 20,000 people. Research suggests that private detention centres are not always cheaper options. ${ }^{101}$ In light of the ineffectiveness of detention as a deterrent and its high cost, states should explore non-custodial means to deal with asylum seekers in order to comply with their human rights obligations. In doing so, states should bear in mind that 'detention is applicable not to those who have committed criminal

97 Kanagaratnam and others v Belgium (App. no. 15297/09), ECtHR, judgment of 13 December 2011, para. 67; Popov v France (App. nos 39472/07 and 39474/07), ECtHR, judgment of 19 January 2012, para. 124.

98 Council Directive 2003/9/EC laying down minimum standards for the reception of asylum seekers [2003] OJ L31.

99 Meijers Committee, above note 76, at 2.

100 Nicholas Keung, 'Tough measures won't stop refugees, Canada told', Toronto Star, 4 January 2012.

101 'A broken, dangerous system', New York Times, 4 December 2011. 
offences but to aliens who, often fearing for their lives, have fled from their own country'. ${ }^{102}$

\section{CONCLUSION}

Western democracies are increasingly caught between implementing accepted rights-based standards of behavior towards asylum seekers, and yielding to political pressures to effectively control their borders. The reinforcement of security-related migration policies and ongoing international cooperation implementing systematic interception and interdiction mechanisms have resulted in the deterioration of asylum seekers' rights.

In this chapter, the securitization of asylum is examined as a speech act not based on reliable evidence and as a process based on policies that criminalize asylum seekers and reduce refugee protection. Recent developments in the EU, in Canada and other Global North states' asylum regimes provide good examples of the devastating effects of the securitization on asylum seekers' rights. State authorities should admit that 'sealing borders' is a fantasy: in democratic states, borders are porous by nature and 'sealing' them would require levels of control and violence incompatible with true democracy and the rule of law. Changing the often inflammatory mainstream political discourse on migration to a balanced one that recognizes state obligations to offer protection to those who are persecuted remains a challenge. Destination states are co-responsible for not curbing the anti-immigration rhetoric that permeates many societies, which in turn pushes for more repressive policies, which result in greater violations of the human rights of asylum seekers. Irregular entry is not per se a crime, neither against persons, nor against property, nor against security: criminalizing illegal entry into a country exceeds the legitimate interest of states to control and regulate irregular immigration and leads to unnecessary detention.

In a context where identity politics push policies toward closure and restriction, but where the law inches unevenly toward greater respect for the human rights of foreigners, it is no wonder that Western states

102 Saadi v United Kingdom (App. no. 13229/03), ECtHR, judgment of 29 January 2008; Report of the United Nations Special Rapporteur on the Human Rights of Migrants, François Crépeau, A/HRC/20/2420 (2012) para. 13; Philip Amaral, From Deprivation to Liberty: Alternatives to Detention in Belgium, Germany and the United Kingdom (Jesuit Refugee Service, 20 December 2011) 12-13. 
increasingly resort to non-entry measures to insulate themselves from claims by asylum seekers. International cooperation as a means of intercepting asylum seekers impedes the right to seek and enjoy asylum. Although the granting of asylum is exercised at the discretion of individual states, international law recognizes an absolute prohibition against forcibly returning a person to a country where that person may be subjected to torture, and thus requires the implementation of effective remedies to guarantee the protection of this right. In addition, according to constitutional, international and regional human rights instruments and mechanisms, states have the obligation to protect the fundamental rights of all persons on their territory or under their control and must take effective action to protect asylum claimants against all forms of human rights violations.

Asylum seekers need to be empowered if their rights are to be guaranteed and discrimination fought. Asylum seekers do not enjoy an easy access to justice, especially when they have come from or through a 'safe country'. Due to tight timelines, detention, reduced procedural safeguards, difficult access to lawyers and NGOs, the number of recognized refugees is steadily decreasing in the EU and in North America. In 2011 , in the EU, the rate of recognition of asylum applicants was 25 percent for first instance decisions. ${ }^{103}$

The detention of asylum seekers has become a widespread migration management tool. States' practice violates human rights principles according to which immigration detention should only be a measure of last resort; applied only in exceptional circumstances and replaced by non-custodial measures whenever possible; prescribed by law; subject to periodic judicial review; lasting only for the minimum time necessary; implemented in appropriate places and conditions; and offering to detainees effective remedies to challenge the lawfulness of their detention. ${ }^{104}$

Reducing irregular migration is a worthy objective. Yet repressive deterrence does not seem to be an adequate response to the phenomenon since interception and interdiction measures do not actually change the migratory pressure in the long term. Asylum movements are related to crises that are appearing unpredictably and will continue to grow due to

103 European Commission, Third Annual Report on Immigration and Asylum, $\operatorname{COM}(2012) 250$ final (2012); 'Asylum decisions in the EU: 27 EU Member States granted protection to 84,100 asylum seekers in 2011', Eurostat, 19 June 2012.

104 François Crépeau, 'Migrants' Rights are Human Rights' in Interights Bulletin on Migrants' Rights (2011). 
armed conflicts and political violence that are increasingly exacerbated by climate change, natural disasters and struggles for scarce resources. Securitization has a huge cost in terms of human life and dignity. ${ }^{105}$

States should recognize that the more they erect tough barriers to the movement of persons, the more smuggling is driven underground and can therefore become a dangerous activity for migrants. The strengthening of action against migrant smuggling, while often couched in the language of protecting vulnerable migrants, may have only served to make smugglers more organized and dangerous, and make migrants more vulnerable to abuse. The solution is definitely to ensure that states' security measures duly respect their obligations regarding the fundamental rights of asylum seekers, since the protection of fundamental rights has become the overarching legitimacy test for all government action. Territorial sovereignty has to be made compatible with existing international and national human rights regimes, and can no longer justify unlimited violations of individuals' rights and freedoms that are based on nationality. Courts and tribunals have and continue to play an important role in the defence of asylum seekers' rights. In recent years, remarkable decisions protecting the rights of migrants have emanated from national supreme courts or regional instances. They have upheld the rights of migrants in the face of public policies that were trampling them with apparent political impunity. One must therefore work hard to support the lawyers and civil society organizations who tirelessly defend migrants in courts, tribunals or national human rights institutions. Such endeavours not only protect the rights of the individual migrants involved, but also serve as precedents and therefore participate in educating the public on asylum seekers' rights, thus contributing to changing public perceptions and fighting negative public discourses and policies.

105 Tineke Strik, Lives Lost in the Mediterranean Sea: Who is Responsible? (Parliamentary Assembly of the Council of Europe, 2012), available at www.statewatch.org/news/2012/apr/coe-med-report-2.pdf. 